\title{
ACCELERATING LOW-COST HOUSING CONSTRUCTION IN INDONESIA: LESSON LEARNED FROM KAMPONG NAGA
}

\author{
Dewi Larasati Z.R. ${ }^{1 *}$, Anjar Primasetra ${ }^{2}$, Suhendri ${ }^{3}$ \\ ${ }^{1,2,3}$ Green Building Research Center, Department of Architecture, SAPPD/School of Architecture, \\ Planning and Policy Development, Institut Teknologi Bandung, Jalan Ganesha 10, Bandung, INDONESIA \\ *Corresponding author; Email: dewizr_ar@yahoo.com
}

\begin{abstract}
Construction methods used in housing development in Indonesia cannot follow the raise in housing needs. Thus, Indonesia is facing a housing backlog up to millions of houses. Prefabricated construction method is one of the solutions that can accelerate housing development. This method has actually been used by some of traditional villages in Indonesia such as Kampong Naga, in West Java. Learning from its local wisdom, this research analyses the traditional prefabricated construction of Kampong Naga as an input for the development of housing development in Indonesia. Qualitative method is used through an observation to the house construction method in Kampong Naga. The result shows that traditional houses in Kampong Naga has a high level of prefabrication, and sustainable in material selection as well as in construction techniques. It is also found that there is an effort from the villagers to expand their prefabricated method to the community outside their village. Regarding to the research results, the local indigenous prefabricated system of Kampong Naga could be considered as a solution for the low cost housing development in Indonesia.
\end{abstract}

Keywords: Local indigenous; local prefabrication; sustainable development; low-cost housing.

\section{INTRODUCTION}

Population growth raises the demand in housing as a primary needs. Unfortunately, housing demand in Indonesia grows faster than the housing development. Thus, housing backlog is becoming larger, current condition up to 8 million houses. In 2010, the data from Ministry of Public Housing of Indonesia shows that at least 8.2 million houses are needed to fulfill the housing demand, while BAPPENAS data shows at least 9 million houses (Menpera, 2011). Moreover, Indonesian Statistic Bureau released a backlog data for housing in Indonesia in 2011 is up to 13.6 million houses. Meanwhile, a survey from SUSENAS (National Socio-Economic Survey) gives 14.2 million of housing backlog.

These data demonstrates an increasing number of housing backlogs in Indonesia, yet this huge demand still cannot be fulfilled by housing development in Indonesia. Innovative methods need to be implemented in order to catch up the backlog. One of the innovations that can be used is prefabricated construction method. Prefabricated construction can build rapidly so it may enhance the number of housing built.

Davidson (2008) mentions that prefabricated technology has evolved in developing countries using local materials and based on low-technology, in the form of local industry. Their products are in simple modules, simplified processes, dedicated services and efficient delivery. The company is an informal construction company, has now shown a strong capacity to respond and adapt to the conditions of the low-cost housing market in developing countries.

The rapid development of the prefabricated housing industry in Japan cannot be separated from the history and culture of Japanese society in building homes. In the past, the Japanese have thought of methods in building a house with a wooden frame structure that was first prepared somewhere and assembled on site and completed with filler walls (Brock, 2011). It can be said that initially, the Japanese people have built their homes with traditional construction prefabrication methods. Learning from Japan, the possibility of developing local prefabricated home industries can evolve based on traditional way.

Traditional community is known for the application this method in construction of their houses. Some of them are Kampong Naga Traditional village in West Java, Minang Community in West Sumatra, and Toraja community in South Celebes. Houses in those traditional communities are firstly built in components, and then be assembled together. Even, Kampong Naga's people has local industry that produced houses to be built outside their village. This research learns from Kampong Naga's prefabricated local construction method in order to utilize the low cost housing construction in Indonesia. 


\section{METHODOLOGY}

Method used in this research is qualitative method, started from literature study to collect secondary data about local indigenous technique of construction, followed by observation and interview to the local people, and examine the existing prefabrication production. Data obtained from the study is then analyzed quantitatively by displaying the findings.

\section{SUSTAINABLE DEVELOPMENT FROM LOCAL INDIGENOUS OF KAMPONG NAGA}

Kampong Naga is one of the traditional villages that is still survive nowadays. It is located in Neglasari Village, Salawu District, Tasikmalaya Regency. Kampong Naga has 118 buildings that are preserved and cared for, consisting of 108 house buildings and 10 public buildings such as mosque, community hall (bale patemon), and big house (rumah ageng). Number of houses and families within the village is constant, and it is stated as one of traditional rules. It is not clear when the traditional village first built. Political instability in Indonesia abolished many of historical data about Kampong Naga. From the interview to the Chief of the traditional village, it is known that the traditional village is built long before the independence year of Indonesia. The preservation of this kampong is started after the stability in Indonesian politic. Between the years of Indonesian independence at 1945 to the beginning of preservation year, this traditional village has been rebuilt twice. Kampong Naga is rebuilt in about 1965 as a result of a huge ide due to a massive riot. The fire was from forest fire that propagates in the indigenous village settlements.

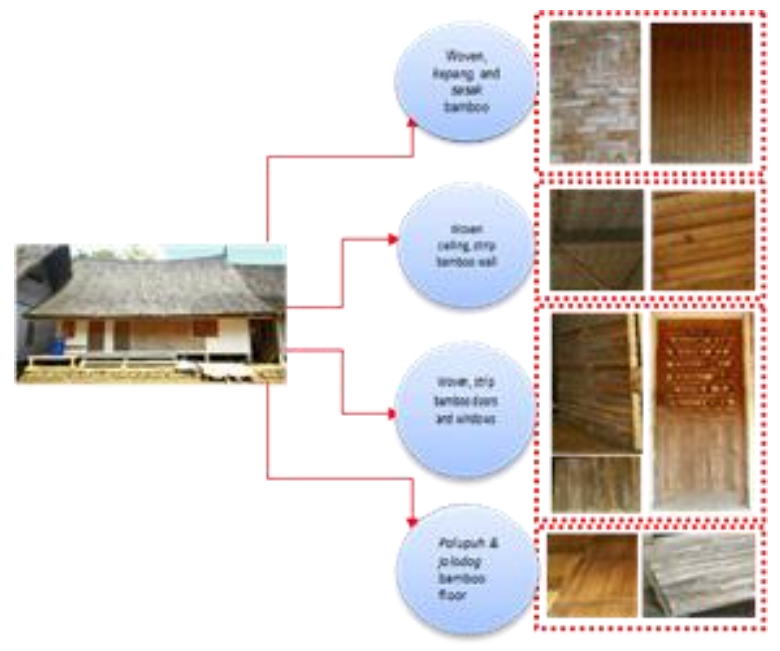

Fig. 1. The use of bamboo material in some elements of Kampong Naga's house
Kampong Naga exploits natural material such as bamboo and timber as building components. In terms of Bamboo preservation method, the villagers also used traditional inherited methods such as a submersion in the preservation pool and coating technique with camphor (Zuraida, et al., 2015).

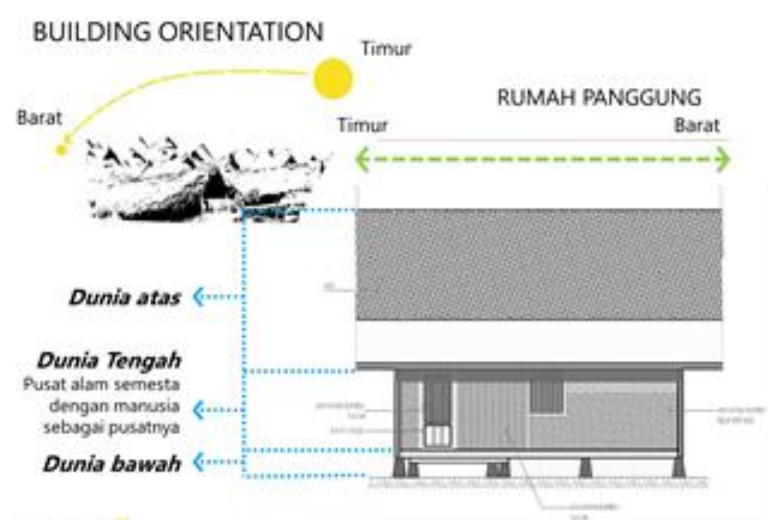

COUPLE BUILDING MASS

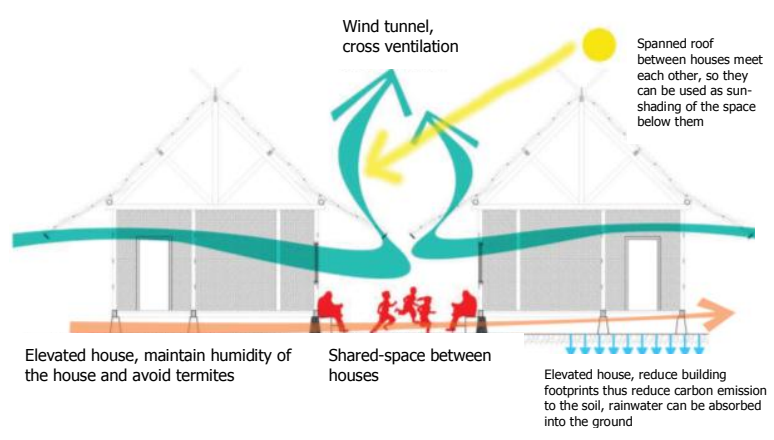

Fig. 2. Implementation of Green Concept in Kampong Naga's house

Based on the observation of some of the indigenous construction of the Kampong Naga is including:

1. The use of bamboo as a sustainable material. Bamboo is a material with a very short harvest period

2. A technique to increase the life span of bamboo, through the harvesting process, the process of preservation and storage

3. Use of the green building concepts in the arrangement of buildings and the construction of residential units

4. The application of the concept of local prefabricated, in improving the quality and the acceleration of the development process

In addition to the building, local wisdom is also seen in the arrangement of village site planning. In the village site area, there is a water sources like a spring in the southern Kampong Naga whose waters never dry even if taken continuously by residents of 
Kampong Naga. It provides a sufficient clean water to eat and drink. Means of production in the form of rice fields are in the west and east settlements. Other production facilities are sung lisung, which is a public building used as a place to pound rice. Another part of Kampong Naga is Sacred Forest located in eastern Kampong. Sacred Forests surrounded by Ciwulan River is the line of demarcation for the area overall sacred forests are sacred. Sacred tomb, which is the tomb of Worship Dalem Singaparna (ancestral Kampong Naga) is located on the west Kampong Naga. Site plan Kampong Naga described in the figure below.

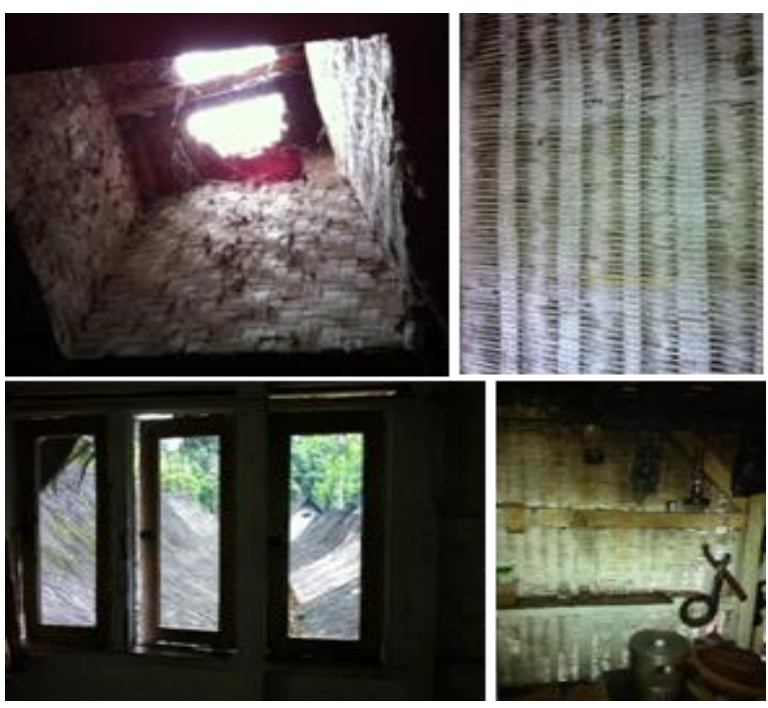

Fig. 3. The use of day lighting in chimney, woven wall, and openings in Kampoong Naga Local House

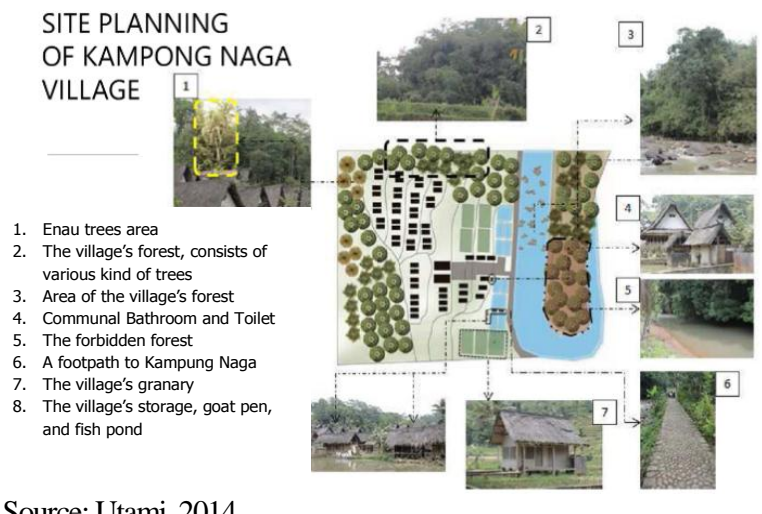

Source: Utami, 2014

Fig. 4. Site plan Kampong Naga

\section{THE DEVELOPMENT OF LOCAL PREFABRICATION METHOD IN KAMPONG NAGA}

Kampong Naga is known for the use of natural material in house construction, especially timber and bamboo. Production of bamboo houses in the village is started from the planting of bamboo, bamboo preservation, to the processing of bamboo into building construction elements such as thatched walls, Palupuh floors, and components of the doors/ windows.

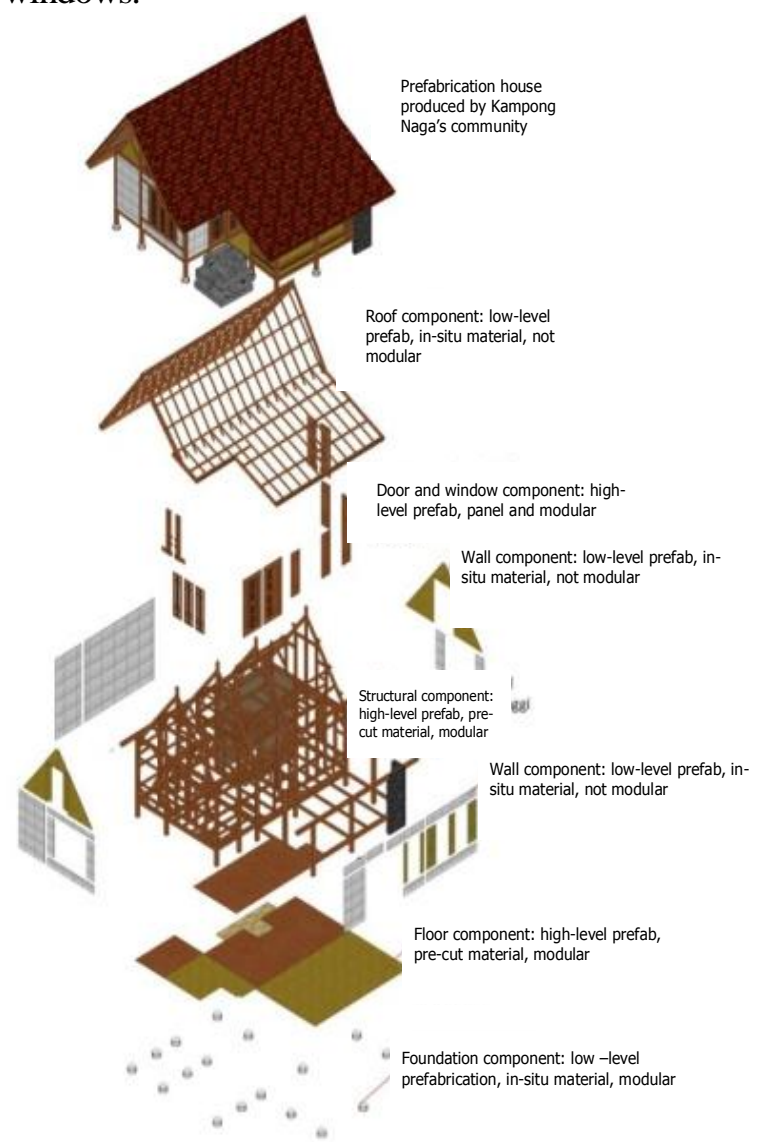

Fig. 5. Prefabrication house of Kampong Naga local community

The prefabricated definition according to Habraken (1972, in Olivia, 2008) is nothing more than the manufacture construction components of off-site and installing them on site, and not necessarily mechanized or produced by machines. The success of prefabricated methods depends on a combination of local factors, such as local resources, economic, and local labor. The origin of prefabricated is that work can be done more quickly and easily in the workshop than on the site.

Prefabricated housing technology is a development system whose construction is built with a system of componentation and installation can be dismantled (Akhmad, 2008). Since, the building components are manufactured and assembled in the workshop (off site), it will facilitate the process of quality assurance that will save the monitoring time. Thus, the construction will be faster than the conventional construction process (on-site) so that the costs incurred will also be reduced. 
In principle, prefabricated method is considered do be a solution to the problems of construction speed, as shown by Figure 6, builders working hours are shorter compared to conventional building methods or on-site construction (McGraw-Hill Construction, 2011).

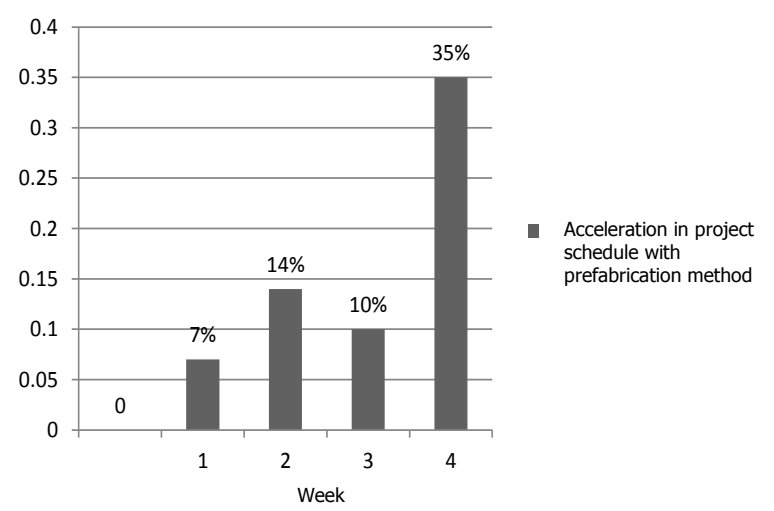

Source: McGraw- Hill Construction 2011

Fig. 6. Acceleration in project schedule with prefabrication method

The picture above shows that over $35 \%$ of the project manager interviews stated that the efficiency of prefabricated method reaches more than 4 weeks than using conventional construction methods. Given the construction of the house takes 12 to 24 weeks, a reduction of 4 weeks to be quite significant.

Kampong Naga prefabricated houses are made of bamboo building components prepared in the workshop with a particular standard which is done using a machine or manual, or a combination of both. From the builders interviewed, prefabricated bamboo products that made si often in the form of cubicle wall of bamboo, Palupuh, laminated bamboo, and bamboo sticks.

Jordan (2011) in writing the benefits and limitations of prefabricated home manufacturing in North America, formulates that prefabricated technology on a housing is divided into two according to its automation level and the assembly components (Bell, 2010; Gibb \& Isack, 2003; Mitchell, 2009; in Jordan, 2011). According to the automation level, prefabricated buildings can be divided into three types, namely: manual, semi-automated, and fully automated. These levels is categorized by the type of equipment used in producing and assembling the prefabricated components.

Manual level is done by human power and without using machine. Semi-automated level is a kind of prefabricated components that uses a mix of human power and machines. Meanwhile, fully automated level is the level of prefabricated components that fully use machine. On the other hand, according to the assembly components, prefabricated types can be divided into two levels, namely high-level prefabricated and low-level prefabricated. Based on the above categories, bamboo products from Kampung Naga can be classified based on their level of prefabrication as described in the Table 1.

Table 1. Classification of prefabrication level in Kampong Naga Traditional House

\begin{tabular}{|c|c|c|c|c|}
\hline No & $\begin{array}{l}\text { Product } \\
\text { Type }\end{array}$ & $\begin{array}{c}\text { Prefab } \\
\text { level }\end{array}$ & $\begin{array}{c}\text { Derivative } \\
\text { Product }\end{array}$ & $\begin{array}{c}\text { Automation } \\
\text { Level }\end{array}$ \\
\hline 1 & $\begin{array}{l}\text { Laminated } \\
\text { bamboo }\end{array}$ & $\begin{array}{l}\text { Low, } \\
\text { material }\end{array}$ & $\begin{array}{l}\text { Column, } \\
\text { Girder, } \\
\text { floor/parquet, } \\
\text { door's and } \\
\text { window's } \\
\text { frame, } \\
\text { furniture }\end{array}$ & $\begin{array}{l}\text { Semi- } \\
\text { automated }\end{array}$ \\
\hline 2 & $\begin{array}{l}\text { Woven } \\
\text { bamboo }\end{array}$ & $\begin{array}{l}\text { High, } \\
\text { component } \\
\text { sub- } \\
\text { assembly, } \\
\text { panels }\end{array}$ & $\begin{array}{l}\text { Bamboo } \\
\text { sunshades, } \\
\text { partition wall, } \\
\text { ceiling, door's } \\
\text { and window's } \\
\text { accessories }\end{array}$ & Manual \\
\hline 3 & Palupuh & $\begin{array}{l}\text { High, } \\
\text { component } \\
\text { sub- } \\
\text { assembly } \\
\text { panels }\end{array}$ & $\begin{array}{l}\text { Partition wall, } \\
\text { floor, furniture } \\
\text { accessories }\end{array}$ & Manual \\
\hline
\end{tabular}

Bamboo prefabricated components are manufactured and sold by the Kampong Naga's people. There are woven wall, door components, window components, and palupuh floor, and even prefabricated housing units. Kampong Naga's people serve the construction of 1 unit knock-down house with timber structure and architectural elements of bamboo. In the development of a house, prefabricated bamboo is processed in a natural way as the process done in the manufacture of custom home construction include bamboo harvesting process appropriate time, preservation by soaking in the tub for at least 3 months, and making components using simple tools or manual.

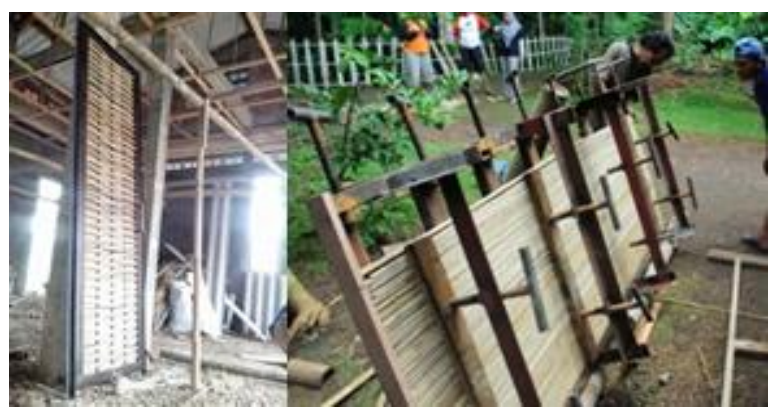

Fig. 7. Level of prefabrication in Kampong Naga's house 
The people of Kampong Naga have begun to introduce their prefabrication products to the outside community. Based on interviews with craftsmen, Kampong Naga serve customers with pre-order system, not with prefabricated product inventory system. Their clients are vary from residential construction to restaurants such as Dusun Bamboo Resort, Stone Cafe restaurant, and Kampong Daun restaurant. Also they build some private houses. However, the production capacity is still low; they even cannot fulfill a demand from Australia as many as 3,000 units of door components due to the low production capacity.
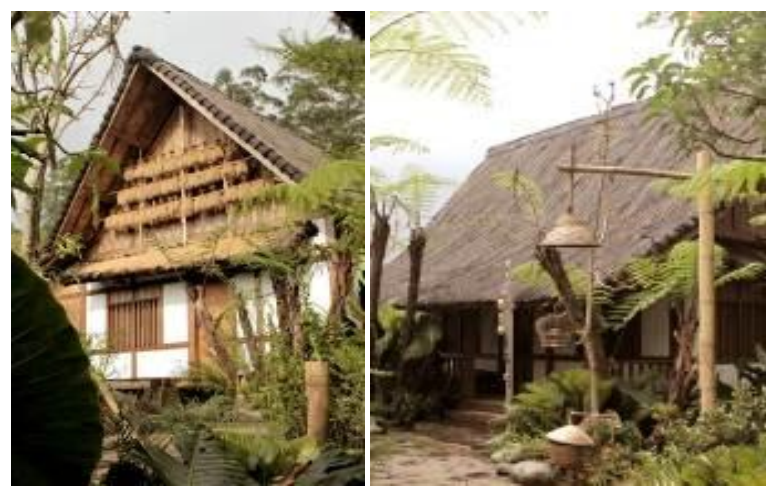

Fig. 8. Products of prefabrication house in Kampong Naga, Lodge unit ini Dusun Bambu Resort (left), Restaurant unit in Kampong Daun Restaurant (right)

\section{ANALYSIS ON THE PROSPECT OF LOCAL PREFABRICATION METHOD}

It is explained in the previous part that market demands for the prefabricated materials and prefabricated house are extensive. Most of the components use bamboo which is already considered as sustainable material. However, the utilization of bamboo is only applicable for architectural component until now. Structural components such as columns, beams, or trusses still use other materials. The utilization of bamboo as architectural components has been developed hereditary, which makes it aesthetically beautiful both in its visual and techniques. Improvement of prefabricated bamboo image as a building material has increased, and expected to become an attractive aesthetic element on the exterior and interior of the house. Combination in the use of bamboo with other materials such as timber could strengthen the character in prefabricated houses.

In terms of architectural design, although the traditional image is still preserved, prefabricated houses produced by Kampong Naga refer to the needs of modern society. It is seen in the bathroom space that is placed inside the home as well as the use of attic room as a bed room. This differs from The original Condet Kampong Naga's house where the bathroom is located outside the house and no room under the roof. Moreover, the modern context is also displayed outside the house as a water tank placed as a water supply to the occupants. Also, other additional installations such as water heaters with gas and water pipe installation.

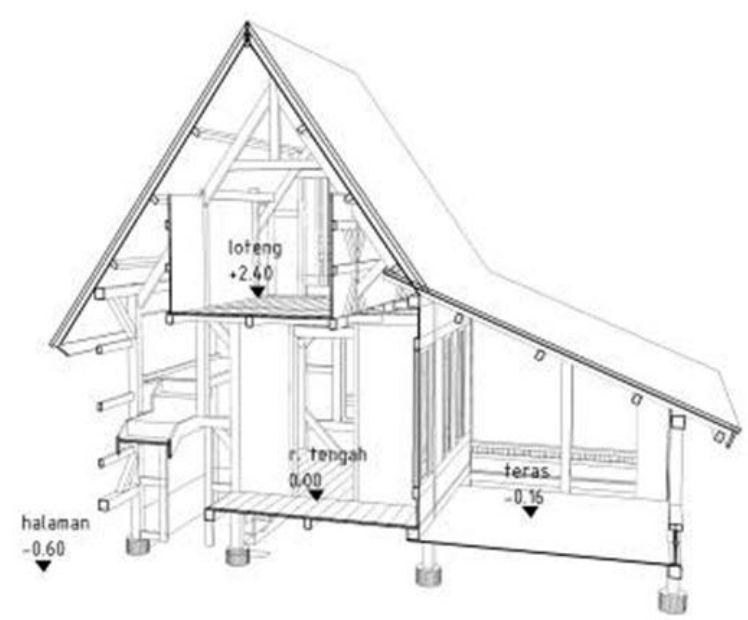

Fig. 9. Local prefabrication house produced by Kampong Naga for outside community

Further, the appearance of the prefabricated house still refer to vernacular house design of Kampong Naga, yet some parts have been adapted to the modern context. The house is still in form of staged house, whit rectangular plan that is raised about $50-60 \mathrm{~cm}$ above the ground. The roof is also still use the traditional style suhunan julang ngapak, a long roof shape extended on both sides, associated to bird's wing span. Columns, girders and floor material use Albasia wood. Wall, kitchen and terrace floor also use bamboo. Adjustment is made in the bathroom area by using ceramic coated stone as floor material, as well as on the front columns coated by stone. In the bedroom there is also a stone wall finishing as an aesthetic element.

The advantages of prefabricated local method of Kampong Naga are rooted from community potential in empowerment of natural and human resources. This is consistent with the description of Amalia (2008) and the theory from Peter Anderson (2007) in his book Prefab Prototypes which states that the main issue of the prefabricated is not only on the primacy of technology, but rather the issue of organization and investment. Organisation issue relates to human and hierarchy of relationships with other humans. Local prefabricated construction industry can be a solution to the problems of housing needs and community empowerment. The aspects that underlie and affect 
local prefabricated construction include architectural aspect, technological aspect, and socio-economic of the society as mentioned by Amalia (2008). Aspects related to local prefabricated Kampong Naga can be explained in the Table 2.

Table 2. Identification of Kampong Naga local prefabrication development

\begin{tabular}{ll}
\hline No. $\quad$ Aspect & \multicolumn{1}{c}{ Analysis } \\
\hline A Architecture & \\
\hline 1 Design context & $\begin{array}{l}\text { Based on occupant's need in } \\
\text { modern lifestyle }\end{array}$ \\
2 Quality of the work & $\begin{array}{l}\text { Fair, limitation in equipment } \\
\text { Good, align with original } \\
\text { 3 Design exploration }\end{array}$ \\
& $\begin{array}{l}\text { Kampong Naga's house and } \\
\text { contextualized in modern }\end{array}$ \\
& context \\
4 Construction & $\begin{array}{l}\text { Knock-down system } \\
\text { Traditional modular dimension }\end{array}$ \\
5 Component &
\end{tabular}

B Technology

1 Component preparation 3-4 weeks time

2 Construction time

3 Material used

4 Material supplier

5 Production workers

6 Assembly workers

7 Component creation method

8 Assembly method in site

9 Transport of the Small truck (1 trip) components

10 Material preservation Fumigation using wood-waste fueled stove and submersion in non-toxic solution

11 Joints Peg

1 Contextual

2 Appropriateness

2 weeks

Bamboo and local timber

Bamboo or timber farmer

3 people

12 people

Semi-automatic (machine and manual work)

Manual

3 Characteristic and the Create a good construction capability of the people product with their techniques

4 Man power 20 people employed in a construction project

5 Income generated Three times higher

Table 2 shows the requirements in developing Kampong Naga's construction method in order to be widely accepted by modern community. The table also strengthens the assumption that the local prefab technology from Kampong Naga could assist the fulfillment of housing backlog in Indonesia. Study of the traditional technology properness reports that $60 \%$ of the products meet the high level prefabrication qualification (Larasati, 2015). Yet, fraction of the products that meets the minimum qualification still needs to be increased.

Vision of the local prefab development is recommended in two aspects, the product and the production system. For the product aspect, it still has weaknesses in the modular components and design exploration. It should accommodate the desire of modern society such as in the diversification of the housing product as well as the completeness of separately-sold product components. In terms of design exploration, architects' role is important in order to create a better image of prefab building in the consumer. Both aspects are planned to be modernized and yet still have roots to the local community and empower them.

For production system aspect, the sustainable value of Kampong Naga's indigenous should be kept during the production. The values are the enhancement of local material utilization, the use of modest technology such as for pant-router machine, also the involvement of other industrial stakeholders. Besides, there is a socio-economic value of the production system that acceptable prefab building is contextual to its site based on the surroundings and social needs.

\section{CONCLUSION}

Kampong Naga is a great example of how a community can provide housing for them as well as assist other communities to build their houses. It is found that the indigenous construction employs local prefabrication method. Thus, it can be said that Kampong Naga's people have developed a local prefabrication construction industry beyond their community. The local construction industry is based on the local materials, local labors, also local construction techniques, and all of them work properly.

However, there are still some disadvantages of the local prefabrication technique to be implemented as a big scale industry. The absence of product standards and quality control, the lack of promotion, and the lengthy time of prefabrication component preparation are among the disadvantages of the industrialization. Nonetheless, there are some advantages that can be learned such as the spirit of togetherness of the people, the empowerment the villagers, the availability of local materials in the village's production forest, the inheritance of construction technique, as well as the sustainable material preservation technique by the people. All of the advantages and disadvantages mentioned above needs to be managed in order to utilize it as one of the solutions for housing development in Indonesia. 
Some conclusions that can be derived from the local wisdom of Kampong Naga in the use of prefabricated construction are mentioned as follows.

- Some of the tradition techniques practiced in Kampong Naga are still relevant today. It is because the technique implements the principles of sustainability.

- Kampong Naga's people have already used prefabrication method with sustainable techniques and materials since a long time ago.

- Kampong Naga's people have also developed their construction method for the communities outside their village, and managed it as a small industry that can generate money for the village.

- Prefabrication method used in Kampong Naga utilize local workforce in the process. Thus, the traditional techniques with high aesthetic value are preserved and inherited from generation to generation.

- Traditional technique tends to be more sustainable and have lower environmental impact. The techniques are potential to be used in modern way.

- Prefabrication level of people in Kampong Naga is surely high, with the componentization system and

- Simple equipment. However, there is still a need to improve the equipment so it can be used to create a panel component system or the higher level sub-assembly components.

- Development of Kampong Naga's construction method with sustainable approach is expected to be one of the solutions for the fulfillment of housing backlog today. The development should be done by adapting the technology to the modern context to wider the acceptance.

\section{REFERENCES}

Anderson, M. \& Anderson, P. (2007). Prefab Prototypes: Site Specific Design for Offsite Construction, Princeton Architectural Press. New York.

Akhmad, A.G. et al. (2008). Disain Rumah Tinggal Konstruksi "Knock Down” (Tinjauan Khusus
Penggunaan Prefabrikasi Lokal). Jurnal SMARTek, 6(1), pp.18-28.

Amalia, A. (2008). Prafabrikasi, antara Arsitektur, Teknologi, dan Sosial Ekonomi. Skripsi. Teknik Arsitektur Fakultas Teknik Universitas Indonesia.

Brock, L. \& Brown, J. (2011). The Prefabricated House in the Twenty-First Century: What Can We Learn from Japan? A Case Study of the KST-Hokkaido House. URL: http://timber.ce. wsu. edu/Resources/papers/4-2-3.pdf

Davidson, C. (2008). Myths and Realities of Prefabrication for Post Disaster Reconstruction. Journal I Rec Building resilience achieving effective post-disaster reconstruction.

McGraw- Hill Construction (2011). Prefabrication and Modularization, Increasing Productivity in Construction industry. Smart Market Report.

Olivia, D. (2008). Studi Desain Dinding Prefabrikasi Rumah Massal Dari Aspek Kecepatan Membangun. Tesis. Institut Teknologi Bandung.

Rippon, J. (2011). The Benefits and Limitations of Prefabricated Home Manufacturing in North America, a Report Submitted in Fulfillment of the Requirements for the Degree of Bachelor of Science in The Faculty of Forestry April 11.

Utami, M.N. et. al. (2014). Kajian Sustainable Material Bambu, Batu, Ijuk dan Kayu pada Bangunan Rumah Adat Kampong Naga. Jurnal Reka Karsa, 2 (2).

Zuraida, S., Larasati, D. \& Wdyowijatnoko, A. (2015). Life Cycle Assessment of Sustainable Housing Material: The Case of Bambo, The Second HabiTechno International Conference Institut Teknologi Bandung, 11 November 2015 Bandung, Indonesia

Larasati, D., Primasetra, A., Victoria, P. \& Fadhly, F.A.R. (2015). Development of CommunityBased Prefabricated Housing Industry to Increase Public Participation in the Fulfillment of Housing Demand. 1st International Conference on Rural Development and Community Empowerment, Institut Teknologi Bandung, Sumedang, Indonesia. 